\title{
PRESENCA DE MECANISMOS ISOMÓRFICOS EM EMPRESAS CONTÁBEIS
}

PRESENCE OF ISOMORPHIC MECHANISMS IN ACCOUNTANCY FIRMS

LA PRESENCIA DE MECANISMOS ISOMÓRFICOS EN LAS EMPRESAS CONTABLES

Ilse Maria Beuren

Doutora

Universidade Regional de Blumenau ilse.beuren@gmail.com

Lara Fabiana Dallabona

Doutoranda

Universidade Regional de Blumenau lara_mestrado@hotmail.com

Submetido em: 13/11/2011

Aprovado em: 13/11/2012

\section{RESUMO}

O estudo objetiva verificar a presença dos três tipos de mecanismos isomórficos (mimético, coercitivo e normativo) da Nova Sociologia Institucional (New Institutional Sociology - NIS) em empresas contábeis. Pesquisa descritiva com abordagem quantitativa foi realizada por meio de levantamento em uma amostra de 122 empresas contábeis do estado de Santa Catarina. Os resultados da pesquisa mostram que nas empresas contábeis das regiões da Grande Florianópolis, Oeste Catarinense e Serra Catarinense predominou o isomorfismo mimético, enquanto que nas regiões Norte Catarinense, Sul e Vale do Itajaí predominou o isomorfismo coercitivo. O isomorfismo normativo não se destacou dentre os demais, porém apresentou forte influência na região Sul Catarinense. A região da Serra Catarinense foi a que apresentou o maior número de empresas com índices que se distanciam do índice médio encontrado para cada tipo de isomorfismo; e a região do Vale do Itajaí, com o menor número de empresas que se distanciam do índice médio. De modo geral, todas as regiões apresentaram e $\left(d_{i}\right)$ próximos a 1 , ou seja, ocorreu pouco distanciamento dos índices de isomorfismo em relação às médias encontradas. Conclui-se que nas empresas pesquisadas há presença, seja em maior ou menor intensidade, dos três tipos de mecanismos isomórficos da Nova Sociologia Institucional.

PALAVRAS-CHAVE: Mecanismos Isomórficos. NIS. Empresas Contábeis.

\section{ABSTRACT}

The goal of this study is to verify the presence of the three types of isomorphic mechanisms (mimetic, coercive and normative) of the New Institutional Sociology (NIS) in accountancy firms. A descriptive research with a quantitative approach was conducted, through a survey with a sample of 122 accounting firms in the Brazilian State of Santa Catarina. The survey results show that in the accounting firms in the regions of Florianópolis, Western Santa Catarina and the Serra Catarinense, the mimetic isomorphism predominated, while in the North and South of the state and Vale do Itajaí region, coercive isomorphism prevailed. Normative isomorphism was not prevalent among the other regions, but had a strong influence in the Southern region of Santa Catarina. The Serra Catarinense presented the highest number of firms with ratios that deviated from the average rate found for each type of isomorphism; and the Vale do Itajaí 
region had few firms that deviated from the average rate. In general, all the regions showed $e\left(d_{i}\right)$ close to 1 , i.e. there was little deviation of the isomorphism rates compared to the averages found. It is concluded that in the firms studied, all three isomorphic mechanisms types of the New Institutional Sociology are present, to a greater or lesser extent.

KEYWORDS: Isomorphic mechanisms. NIS. Accounting firms.

\section{RESUMEN}

Este estudio tiene como objetivo verificar la presencia de los tres tipos de mecanismos isomórficos (mimético, coercitivo y normativo) de la Nueva Sociología Institucional (New Institutional Sociology - NIS) en empresas contables. Se realizó una investigación descriptiva con abordaje cuantitativo por medio de relevamiento en una muestra de 122 empresas contables del estado de Santa Catarina. Los resultados de la investigación muestran que en las empresas contables de las regiones de la Gran Florianópolis, Oeste Catarinense y Sierra Catarinense predominó el isomorfismo mimético, mientras que en las regiones Norte Catarinense, Sur y Valle del Itajaí predominó el isomorfismo coercitivo. El isomorfismo normativo no se destacó entre los demás, pero presentó fuerte influencia en la región Sur Catarinense. La región de la Sierra Catarinense fue la que presentó el mayor número de empresas con índices que se alejan del índice medio encontrado para cada tipo de isomorfismo; y la región del Valle del Itajaí, con el menor número de empresas que se alejan del índice medio. De modo general, todas las regiones presentaron $\mathrm{e}\left(\mathrm{d}_{\mathrm{i}}\right)$ próximos a 1 , es decir, ocurrió poco distanciamiento de los índices de isomorfismo en relación a las medias encontradas. Se concluye que en las empresas estudiadas hay presencia, en mayor o menor intensidad, de los tres tipos de mecanismos isomórficos de la Nueva Sociología Institucional.

PALABRAS CLAVE: Mecanismos Isomórficos. NIS. Empresas Contables.

\section{INTRODUÇÃO}

Para que as empresas possam continuar as relações entre fornecedores e clientes, elas dependem, dentre outros fatores, da satisfação de ambas as partes com o resultado oferecido pelas transações que realizam entre si (MORAES JUNIOR; ARAÚJO, 2006). Nesta perspectiva, as empresas contábeis precisam atender seus clientes com serviços de qualidade, por meio de uma equipe treinada, buscando adequar-se ao ambiente em que atuam para melhor executar suas tarefas e satisfazer as exigências dos seus clientes.

O objetivo básico da contabilidade, segundo Iudícibus (2004), resume-se em gerar e fornecer informações econômicas para os vários stakeholders, proporcionando decisões de forma racional. No entanto o autor alerta que nem todos os detalhes dos modelos decisórios dos usuários são de conhecimento dos elaboradores dessas informações. A contabilidade precisa gerar informações com qualidade, atendendo exigências dos usuários internos e externos das empresas, para que possam conhecer melhor a situação sob análise. Nesse processo, a empresa contábil pode basear-se em outras do mesmo ramo para se adequar às exigências dos seus usuários.

Neste sentido, os mecanismos isomórficos previstos na teoria institucional podem contribuir para a melhoria dos serviços contábeis. Freitas (2005) relata que a teoria institucional visa explicar como e por que as organizações surgem, tornam-se estáveis ou são transformadas, bem como são estruturadas as formas e a cultura organizacional. O processo pelo qual as organizações são forçadas a adotarem estruturas e sistemas similares a outras empresas, tornando suas práticas similares entre si, num dado setor organizacional, é designado por isomorfismo (DIMAGGIO; POWELL, 1983).

A Teoria Institucional, na vertente da Nova Sociologia Institucional (New Institutional Sociology NIS), aborda três tipos de mecanismos isomórficos no processo de institucionalização: isomorfismo coercitivo, isomorfismo mimético, isomorfismo normativo (DIMAGGIO; POWELL, 1983). Os tipos de 
mecanismos isomórficos podem ser identificados nas atividades internas e/ou externas das empresas que se apresentam semelhantes, ou até mesmo por meio de atitudes e práticas dos seus membros. Por esse motivo, presume-se que as empresas contábeis tenham grande probabilidade de ocorrência de isomorfismo entre si, pois apresentam similaridades em ambientes semelhantes.

Estudos pautados em diferentes vertentes da teoria institucional foram realizados com enfoques diversos da gestão, como o de Rossetto (2003), com foco na formulação estratégica; de Gimenez, Hayashi Junior e Grave (2007) no posicionamento estratégico; de Machado-da-Silva e Coser (2006) nas relações interorganizacionais; de Carstens e Machado-da-Silva (2006) nos relacionamentos de uma rede de organizações; de Sacomano Neto, Truzzi e Kirschbaum (2010) na relação entre uma montadora de veículos e seus fornecedores; de Coraiola e Machado-da-Silva (2008) nas mudanças de projeto gráfico de jornais brasileiros. Destacam-se também as pesquisas que relacionaram a teoria institucional com o controle gerencial, como as de Frezatti, Aguiar e Rezende (2007), Oyadomari et al. (2007), Guerreiro, Pereira e Frezatti (2008), Oyadomari et al. (2008), Fachini, Beuren e Nascimento (2009).

Na revisão da literatura, uma lacuna de pesquisa foi percebida em um setor específico, no caso as empresas contábeis. A identificação dos tipos de mecanismos isomórficos, se coercitivos, miméticos ou normativos, pode ocorrer a partir da comparação das atividades rotineiras realizadas em empresas contábeis. A presença de isomorfismo nestas empresas é possível entre profissionais que atuam nessa área, no processo de gestão das empresas, na prestação dos serviços de contabilidade e nas informações contábeis que são transmitidas para atender seus clientes, fornecedores, governo, entre outros usuários dos serviços contábeis.

Diante do exposto, formulou-se a seguinte pergunta de pesquisa: Quais dos três tipos de mecanismos isomórficos mais se destacam nas empresas contábeis do estado de Santa Catarina? Para responder essa questão de pesquisa, o estudo tem por objetivo verificar a presença dos três tipos de mecanismos isomórficos (mimético, coercitivo e normativo) da Nova Sociologia Institucional (New Institutional Sociology - NIS) nas empresas contábeis. Santa Catarina é o sexto maior em número de empresas contábeis no Brasil, conforme estatísticas do Conselho Federal de Contabilidade. Estes números e a disponibilização da listagem das empresas foram motivadores para realizar a pesquisa no campo delimitado.

O estudo justifica-se por verificar como as empresas contábeis são semelhantes entre si, quer seja em sua estrutura ou em suas práticas. Analisam-se os tipos de mecanismos isomórficos presentes no âmbito dessas organizações a partir dos controles de gestão adotados, das atividades desenvolvidas e das exigências que lhe são impostas. Pretende-se contribuir, ao investigar a presença dos mecanismos isomórficos no campo específico das empresas contábeis, dada a relevância da identificação de mudanças institucionais no ambiente em que atuam, seja por imposições legais, de inovação ou profissionais.

\section{TEORIA INSTITUCIONAL NA VERTENTE DA NEW INSTITUTIONAL SOCIOLOGY (NIS)}

Na perspectiva institucional, as organizações estão interligadas. Como as empresas necessitam de uma produção que Ihes assegure a sua continuidade, a visão institucional argumenta que as organizações precisam ter legitimidade de seus interessados ou beneficiários. A legitimidade pode ser compreendida como a perspectiva de que as ações de uma organização venham a ser desejáveis, corretas e apropriadas dentro do sistema de normas, valores e crenças do ambiente que estão inseridas (DAFT, 1999).

Guerreiro, Pereira e Lopes (2004, p. 7) explicam que "a institucionalização refere-se a um processo adaptativo através do qual as expectativas sociais da forma mais apropriada de se organizar e de se comportar leva em conta determinadas regras vigentes". A teoria institucional vem sendo explorada em âmbito internacional e nacional para explicar práticas relacionadas à contabilidade gerencial.

$O$ interesse na teoria institucional envolve praticamente três enfoques que podem ser observados na literatura: Nova Sociologia Institucional (New Institutional Sociology - NIS), Nova Economia Institucional (New Institutional Economics - NIE) e Velha Economia Institucional (Old Institutional 
Economics - OIE) (MACHADO-DA-SILVA; FONSECA, 1993; BARLEY; TOLBERT, 1997; TOLBERT; ZUCKER, 1999; MACHADO-DA-SILVA; FONSECA; CRUBELLATE, 2005; GUERREIRO, 2006).

Rossetto e Rossetto (2005) reportam que as primeiras versões da teoria institucional buscaram enfatizar o caráter legitimado das regras institucionalizadas, bem como os mitos e crenças que moldam a realidade social, assim como o processo por meio do qual as organizações tendem a tornar-se repletas de valor e significância social. Por meio da perspectiva institucional, é possível conceber o desenho das organizações, não como um processo racional, mas sim como um processo que deriva de pressões externas e internas, que levam as empresas a se tornarem similares uma com as outras.

Amaral Filho e Machado-da-Silva (2006) mencionam que a teoria institucional é reflexo da busca pelas adaptações auferidas por parte das organizações quanto às normas que socialmente foram criadas e legitimadas. Os autores citam que as empresas precisam "adequar suas estruturas e práticas às exigências ambientais, uma vez que tal conformação lhes possibilita obter legitimidade institucional e, conseqüentemente, perpetuar o seu funcionamento interno e aumentar as suas chances de sobrevivência" (AMARAL FILHO; MACHADO-DA-SILVA, 2006, p. 2).

A Teoria Institucional na vertente da Nova Economia Institucional (New Institutional Economics - NIE), segundo Ribeiro e Scapens (2006), propõe que a afirmação fundamental é que algumas das organizações envolvem ambientes institucionalizados. Esses ambientes não estão focados somente com questões de relacionamento com clientes, fornecedores, etc., e sim envolvem regras culturais e normas sociais que relacionam determinadas estruturas e procedimentos formais das organizações.

Neste estudo será considerada a vertente da Nova Sociologia Institucional (NIS), com foco para o isomorfismo institucional, por envolver questões relacionadas à similaridade das empresas contábeis. Na vertente da Nova Sociologia Institucional, leva-se em conta que as organizações, para que possam assegurar sua sobrevivência e continuidade no mercado, precisam se conformar às normas sociais de comportamento aceitável, além de atingir diversos níveis de eficiência produtiva (GUERREIRO, 2006).

\section{ISOMORFISMO INSTITUCIONAL}

De acordo com Daft (1999), o isomorfismo institucional é retratado pelo surgimento de estruturas e abordagens comuns originadas entre as organizações pertencentes a um mesmo setor. O pressuposto do isomorfismo é centrado no fato de que as empresas buscam mudanças institucionais similares a outras empresas que já estão ajustadas ao ambiente em que atuam, das quais já obtiveram sucesso profissional (ROSSETTO; ROSSETO, 2005).

Os relacionamentos inter-organizacionais fazem com que as organizações de um mesmo setor apresentem similaridades entre si. Destaca-se, portanto, que a legitimidade se faz presente no contexto do isomorfismo, visto que "o isomorfismo pode ser entendido como a busca da homogeneidade de estruturas, processos e ações no âmbito das organizações" (FREITAS, 2005, p. 20).

Rezende e Guerreiro (2010) afirmam que, na teoria institucional, a abordagem do isomorfismo institucional refere-se a todas as forças que levam as empresas a se tornarem similares. Segundo Machado-da-Silva e Fonseca (1993, p.30), "o motivo que leva uma organização a adotar posturas isomórficas em relação aos líderes do seu campo organizacional é autodefesa diante de situações sem soluções geradas internamente, uma vez que a semelhança facilita as transações interorganizacionais".

DiMaggio e Powell (1983) apresentam três mecanismos de mudança institucional isomórfica: isomorfismo coercitivo, isomorfismo mimético e isomorfismo normativo. O Quadro 1 ilustra cada um desses tipos de mecanismos isomórficos para a adaptação institucional em organizações. 
Quadro 1: Mecanismos isomórficos para a adaptação institucional

\begin{tabular}{|l|l|l|l|}
\hline Adaptações & Mimético & Normativo & Coercitivo \\
\hline $\begin{array}{l}\text { Motivos para se } \\
\text { adaptar }\end{array}$ & Incerteza & Dever, obrigação & Dependência \\
\hline Carreira & Visibilidade da inovação & $\begin{array}{l}\text { Profissionalismo, } \\
\text { certificados, credenciamento }\end{array}$ & $\begin{array}{l}\text { Leis, regras e sanções } \\
\text { políticas }\end{array}$ \\
\hline Base social & Culturalmente apoiada & Moral & Legal \\
\hline Exemplos & $\begin{array}{l}\text { Reengenharia, } \\
\text { Benchmarking }\end{array}$ & $\begin{array}{l}\text { Padrões contábeis, } \\
\text { treinamento com } \\
\text { consultores }\end{array}$ & $\begin{array}{l}\text { Controle de poluição, } \\
\text { regulamentos escolares }\end{array}$ \\
\hline
\end{tabular}

Fonte: Adaptado de Daft (1999, p. 348).

Observa-se no Quadro 1 que o isomorfismo mimético está relacionado ao ambiente de incertezas ambientais, no qual as organizações podem copiar a si mesmas, baseando-se em outras organizações percebidas como casos de sucesso. As organizações procuram copiar os modelos de qualidade e excelência como uma maneira de minimizar a incerteza no âmbito organizacional (PASSALONGO; ICHIKAWA; REIS, 2004). Daft (1999) cita como exemplo de isomorfismo mimético a técnica do benchmarking. O autor explica que benchmarking significa identificar a melhor opção de uma atividade comercial e posteriormente a duplicação de tal técnica para buscar excelência ou, até mesmo, para aperfeiçoar e melhorar o processo.

O isomorfismo mimético entre as organizações, conforme Fachini, Beuren e Nascimento (2009, p. 5), "pode acontecer por transferência de funcionários de uma mesma indústria, bem como pela contratação de consultorias externas que atendam a mais de uma empresa atuante no mesmo setor". Os autores relatam ainda que "a afirmação sobre essa vertente de isomorfismo tem como base a tendência de as organizações tomarem como modelo em seu campo organizacional, outras organizações que elas julgam ser mais legítimas ou bem-sucedidas".

O isomorfismo normativo está relacionado aos profissionais e aos trabalhadores dentro de um determinado campo organizacional, como, por exemplo, a educação formal ou a formação prática relacionada à área em que atuam. Para Daft (1999, p. 348), o "isomorfismo normativo significa que as organizações mudam para atender padrões de profissionalismo, para adotar técnicas que são consideradas pela comunidade profissional como atualizadas e eficazes". O autor menciona que "os profissionais compartilham uma educação formal baseada nos graus universitários e em redes profissionais por meio das quais são trocadas idéias por consultores e líderes profissionais".

O isomorfismo coercitivo é resultado de influências políticas e do problema da legitimação como resultado de pressões formais e informais, exercidas por outras organizações e pela sociedade na qual as empresas atuam (DIMAGGIO; POWELL, 1983). De acordo com Daft (1999), o isomorfismo coercitivo decorre da pressão externa que é exercida sobre as organizações para que busquem adotar determinadas estruturas, técnicas e até mesmo procedimentos similares a outras organizações.

Para Passalongo, Ichikawa e Reis (2004), existindo um ambiente legal comum, este afetará vários aspectos inerentes ao comportamento, à estrutura e à cultura organizacional. Dessa forma, as estruturas organizacionais refletirão as regras institucionalizadas e legitimadas pelo estado. Diante disso, as mudanças no comportamento, bem como na estrutura das organizações, podem ocorrer tanto por pressões governamentais por meio de leis, normas e regulamentos, bem como por pressões externas ou internas (clientes, fornecedores, stakeholders, entre outros).

Após as definições de cada tipo de mecanismo isomórfico, verifica-se a probabilidade de as empresas apresentarem em determinado momento, alguma característica predominante de isomorfismo, tanto mimética, normativa ou coercitiva. O Quadro 2 relaciona os três tipos de mecanismos isomórficos (mimético, normativo coercitivo), apresentando o nível organizacional comparado ao nível do campo organizacional (empresa). 
Quadro 2: Mecanismos isomórficos em nível organizacional e campo organizacional

\begin{tabular}{|l|l|l|}
\hline Isomorfismo & Nível organizacional & Nível do campo organizacional \\
\hline \multirow{5}{*}{ Mimético } & $\begin{array}{l}\text { Quanto maior a incerteza, mais as } \\
\text { organizações tendem a copiar modelos } \\
\text { bem-sucedidos. }\end{array}$ & $\begin{array}{l}\text { Quanto menor o número de organizações } \\
\text { utilizadas como modelo, mais rápido é o } \\
\text { processo de isomorfismo. }\end{array}$ \\
\cline { 2 - 4 } Normativo & $\begin{array}{l}\text { Quanto maior a ambigüidade das metas, } \\
\text { maior a probabilidade das organizações } \\
\text { imitarem as ações bem-sucedidas de } \\
\text { outras organizações. }\end{array}$ & $\begin{array}{l}\text { Quanto maior a incerteza tecnológica, } \\
\text { maior o padrão de isomorfismo entre as } \\
\text { organizações. }\end{array}$ \\
\hline \multirow{2}{*}{ Coercitivo } & $\begin{array}{l}\text { Quanto maior a participação dos } \\
\text { associações profissionais, maior a } \\
\text { similaridade entre as organizações. }\end{array}$ & $\begin{array}{l}\text { Quanto maior o profissionalismo no } \\
\text { campo, maior o grau de isomorfismo. }\end{array}$ \\
\cline { 2 - 4 } & $\begin{array}{l}\text { Quanto mais dependentes são as } \\
\text { organizações, mais parecidas elas se } \\
\text { tornarão. }\end{array}$ & $\begin{array}{l}\text { Quanto maior a centralização no } \\
\text { suprimento de recursos, maior a } \\
\text { dependência das outras organizações. } \\
\text { recurso, maior o grau de isomorfismo. }\end{array}$ \\
\hline
\end{tabular}

Fonte: Adaptado de Dimaggio e Powell (1991).

Verifica-se, no Quadro 2, que o mecanismo mimético é influenciado pelas incertezas causadas no ambiente organizacional. Quanto maior for o grau de incerteza perante os acontecimentos internos e externos das organizações, maior será o grau de isomorfismo mimético, já que buscarão copiar modelos bem-sucedidos de outras empresas para auferir melhores resultados.

O mecanismo normativo é influenciado pela qualidade e exigência das empresas perante a profissionalização dos colaboradores. Empresas que apresentam profissionais qualificados, com titulação acadêmica e experiência profissional, apresentam maior grau de isomorfismo normativo. Já o mecanismo isomórfico coercitivo tem forte relação com o estado, com as imposições legais que Ihes são atribuídas. A dependência das empresas dos órgãos governamentais refletirá o grau desse isomorfismo.

\section{PESQUISAS EMPÍRICAS PUBLICADAS SOBRE ISOMORFISMO}

A seleção das pesquisas decorreu da leitura de trabalhos publicados em anais [Congresso ANPCONT; Congresso USP de Controladoria e Contabilidade; Encontro da ANPAD (EnANPAD); Encontro de Estudos sobre Empreendedorismo e Gestão de Pequenas Empresas (EGEPE)], e de artigos em periódicos [Revista de Administração Contemporânea (RAC); Revista de Administração de Empresas (RAE); Revista de Administração Mackenzie; Organizações \& Sociedade], que abordaram a teoria institucional sob a ótica do isomorfismo. A delimitação desta forma de busca teve como propósito fundamentar o estudo empírico, ao mesmo tempo em que sinaliza uma limitação de escopo da base teórica. As pesquisas localizadas neste sistema de busca estão descritas abaixo de forma breve.

Rossetto (2003) investigou, por meio de um estudo multicasos, como o isomorfismo institucional influenciou a formulação estratégica de três empresas do ramo da construção civil, relativo ao setor de edificações, localizadas na cidade de Florianópolis/SC, analisando as adaptações de estratégias em ambientes com fortes turbulências e influências governamentais. O autor concluiu que dos processos de adaptação estratégica analisados, os isomorfismos institucionais que obtiveram maior influência no contexto de formulações estratégicas foram os isomorfismos mimético e coercitivo. Já o isomorfismo normativo foi o que apresentou menor intensidade entre as estratégias analisadas.

Machado-da-Silva e Coser (2006) desenvolveram uma pesquisa com o objetivo de verificar as relações interorganizacionais entre 40 organizações do município de Videira, no Estado de Santa Catarina, a partir de uma organização focal. Os autores basearam-se teoricamente no conceito da teoria institucional, com foco para as estruturas institucionais regulativas, normativas e cognitivas. 
Foram analisadas 40 organizações que desenvolvem atividades com a finalidade de dar suporte a um ciclo produtivo agroindustrial orquestrado por uma organização focal em Videira - SC, por meio de entrevistas semiestruturadas e questionários com perguntas fechadas para atingir ao objetivo proposto. Os resultados demonstram diferentes esferas e níveis de influência da organização focal sobre as estruturas institucionais, com implicações para a ocorrência de isomorfismos nas organizações, o que ressalta a importância de uso de uma perspectiva multiparadigmática para o entendimento e o tratamento do conceito de campo organizacional.

Carstens e Machado-da-Silva (2006) realizaram um estudo com o objetivo de verificar de que maneira a estrutura de relacionamentos de uma rede de organizações do setor farmacêutico influenciou a adoção de estratégias pelas empresas participantes. As empresas que compõem as redes interorganizacionais perfizeram um total de 40 empresas localizadas na Região Metropolitana de Curitiba e no município de Itapema-SC. Os autores constataram que o papel da administração central dentro da rede de empresas analisadas possui caráter fundamentalmente regulativo, coercitivo e normativo em menor grau. Os autores destacam o relevante papel da administração na aplicação de multas, sanções e demais penalidades pelo comportamento 'inadequado' aos padrões estabelecidos. No que tange aos demais integrantes da rede, estes apresentaram um comportamento mimético e normativo em menor grau.

Gimenez, Hayashi Junior e Grave (2007) investigaram como uma ferramenta de análise de posicionamento estratégico, baseada na psicologia dos construtos pessoais, pode auxiliar na identificação de isomorfismo estratégico, contribuindo para maior integração entre as abordagens institucionalista e cognitiva de estratégia, por meio da operacionalização da grade de repertório de Kelly (1955). No que tange à posição estratégica atual, esta indicou isomorfismo para $64 \%$ das empresas analisadas, ao passo que a posição estratégica futura elevou esse porcentual para $86 \%$. Os dados apontaram para uma crescente homogeneização estratégica, pelo menos ao nível da intenção. A diferenciação nas escolhas estratégicas pode, talvez, ser explicada por um enfoque na cognição dos estrategistas. A cognição, por estar intimamente associada aos processos de percepção ambiental, pode levar à construção de um ambiente particular na mente do estrategista, que ajude a explicar fugas da homogeneização.

Oyadomari et al. (2007) buscaram analisar e entender quais são os fatores que favoreceram a institucionalização da Value Based Management (VBM), à luz dos argumentos de teóricos da vertente NIS. A pesquisa foi desenvolvida por meio de um ensaio no qual há uma análise dos principais autores em teoria institucional na vertente NIS, refletindo sobre a teoria e o processo de institucionalização do VBM. Obtiveram como resultados reflexos de uma análise crítica que comparou os acontecimentos com as teorias da NIS, concluindo que a institucionalização da VBM sustentou-se fortemente no pilar cognitivo-cultural, com a utilização do mecanismo mimético. O estudo demonstrou também uma relevante necessidade dos administradores legitimarem suas ações perante os acionistas, 0 que se materializa pela adoção do VBM.

Frezatti, Aguiar e Rezende (2007) desenvolveram uma pesquisa de campo, aplicando um questionário estruturado, buscando analisar o grupo gerencial de uma empresa multinacional fabricante de insumos para produtos duráveis. O estudo objetivou analisar a potencialidade do modelo desenvolvido por Oliver (1991), em conjunto com a abordagem do processo de institucionalização proposto por Tolbert e Zucker (1999), para o entendimento, a análise e a atuação sobre a intensidade das respostas estratégicas às pressões institucionais decorrentes da demanda pelo processo de elaboração do orçamento em uma entidade. Dentre os resultados obtidos, os autores destacam que os gestores, ao alcançarem metas, têm uma tendência de responder às pressões estratégicas da forma mais ativa, conforme proposto por Oliver, ou seja, manipulando. Neste caso, a utilidade da informação obtida, mensurando o grau de institucionalização, está ligada à gestão dos executivos e à sua possibilidade de atuar de maneira objetiva para que a institucionalização ocorra em benefício da entidade.

Guerreiro, Pereira e Frezatti (2008) testaram a aplicabilidade do modelo de Burns e Scapens (2000) para avaliar o processo de institucionalização da contabilidade gerencial por meio de um estudo de caso, analisando a implantação de contabilidade gerencial em uma organização bancária brasileira. Como resultados desta aplicação, os autores concluíram que o respectivo modelo pode ser utilizado como referência conceitual para avaliação dos processos de mudanças de sistemas de contabilidade gerencial, uma vez que este modelo facilita análises operacionais do processo de 
institucionalização. Concluíram que o processo de incorporação das novas regras e rotinas codificadas pelos gestores se desenvolveu de forma efetiva por meio das ações de treinamento promovidas pela área de controladoria do Banco, baseadas nos conceitos e nos indicadores do novo sistema de contabilidade gerencial.

Oyadomari et al. (2008) identificaram os fatores que influenciam as empresas brasileiras no processo de adoção de práticas e instrumentos de contabilidade gerencial, sob a ótica da NIS, agrupando-os de acordo com os tipos de isomorfismos. O estudo foi de caráter exploratório, utilizando uma amostra não probabilística de 27 empresas de médio e grande porte, extraídas das Revistas Valor 1000 Maiores Empresas, edição de 2006, para as quais foi enviado um questionário estruturado com questões fechadas. Os autores concluíram que ocorreu adoção cerimonial na implementação dos artefatos; o isomorfismo mimético destacou-se como o mais importante na adoção dos mesmos; obtenção de conhecimentos sobre novos artefatos ocorreu pela forma de socialização do conhecimento; as consultorias apresentaram papel relevante na adoção de tais artefatos; pela imposição dos acionistas ser pequena, minimizou o mecanismo coercitivo; e a decisão de escolhas dos artefatos foi direcionada pelo corpo diretivo e gerencial da empresa.

Coraiola e Machado-da-Silva (2008) buscaram verificar o fenômeno do isomorfismo nas mudanças de projeto gráfico de jornais brasileiros, mediante a análise da influência exercida pelos discursos de três grupos de profissionais: gestores, jornalistas e designers. Conforme apresentado pelos autores, o estudo indica a existência de relativo consenso em relação ao aumento da valorização das modificações em projetos gráficos no campo jornalístico, bem como no que concerne aos aspectos que devem ser modificados e ao tipo de mudanças que devem ser realizadas. Outra constatação por parte dos autores está em relação à existência de perspectivas diferenciadas para os três grupos de profissionais e existência de embates, negociações e significações processadas pelos discursos dos grupos que contribuem para a construção dos padrões existentes no campo organizacional analisado.

Fachini, Beuren e Nascimento (2009) verificaram evidências de isomorfismo nas funções da controladoria das empresas familiares têxteis de Santa Catarina. A pesquisa foi realizada por meio de survey, tendo como população da pesquisa as 46 empresas familiares associadas ao Sindicato das Indústrias de Fiação, Tecelagem e do Vestuário (Sintex) de Blumenau. Os autores concluíram que existe um grau significativo de isomorfismo na maioria das funções da controladoria das empresas familiares pesquisadas, considerando-se o grau de importância atribuído pelos respondentes às atividades distribuídas nas nove funções apontadas (função contábil; função de controles internos; função de custos; função de controle operacional; função de gestão da informação; função gerencial/estratégica; função de controles de riscos; função tributária; e, função de proteção e controles de ativos).

Rossoni e Machado-da-Silva (2010) desenvolveram um ensaio teórico delineando uma visão institucional acerca da governança corporativa, destacando suas dimensões e suas instituições, bem como o processo de institucionalização de tais práticas. Fator de destaque é dado para a legitimação da governança corporativa, uma vez que a legitimidade constitui ponto central no institucionalismo organizacional. A principal contribuição do respectivo ensaio teórico são as implicações de se compreender as práticas de governança, com enfoque no institucionalismo organizacional, no qual apresentam uma série de possibilidades para o desenvolvimento de estudos futuros.

Sacomano Neto, Truzzi e Kirschbaum (2010) desenvolveram um estudo com o objetivo de analisar como o isomorfismo institucional e a capacidade de controle geram estruturas de coordenação estáveis na relação entre uma montadora de veículos e seus fornecedores em uma planta modular. O estudo foi desenvolvido por meio de estudos de caso e entrevistas realizadas com o diretor de produção da respectiva montadora e dois diretores de produção dos fornecedores. Os resultados apresentam que quanto maior for o grau de dependência de uma organização em relação à outra, maior será a similaridade desta organização à outra em termos de estrutura, ambiente e foco comportamental. Outra constatação decorre do fato de que atores sociais hábeis encontram formas de aplicar recursos e regras formais e informais existentes na produção de ordens locais e institucionais para o lançamento e desenvolvimento da planta modular.

Esta pesquisa difere dos estudos apresentados, haja vista que busca verificar dentre os três tipos de mecanismos isomórficos (mimético, normativo e coercitivo), quais se destacam nas empresas contábeis do estado de Santa Catarina. Embora o estudo se aproxime dos apontados no que diz 
respeito à base teórica, se distancia no campo da pesquisa e no constructo que consubstancia a pesquisa de campo.

\section{PROCEDIMENTOS METODOLÓGICOS}

Pesquisa descritiva, conforme preceitua Martins (2002), foi realizada por meio de levantamento, com abordagem quantitativa do problema. Neste estudo, descrevem-se aspectos inerentes à população da pesquisa, que compreende as empresas contábeis do Estado de Santa Catarina, sobre a presença dos tipos predominantes de isomorfismo. A pesquisa é tipificada como pesquisa de levantamento ou survey, conforme concepção de Gil (1999), haja vista que a coleta de dados foi efetuada por meio da aplicação de um questionário na população alvo.

$\mathrm{O}$ instrumento de pesquisa utilizado centra-se em um questionário com perguntas do tipo escala Likert. Segundo Martins e Theóphilo (2007, p. 90), "trata-se de um conjunto ordenado e consistente de perguntas a respeito de variáveis e situações que se deseja medir ou descrever". O questionário foi estruturado em três blocos, um para cada mecanismo isomórfico (mimético, normativo e coercitivo). Algumas questões foram inspiradas no estudo de Müller e Beuren (2008) e de Oyadomari et al. (2008). Um teste piloto foi realizado com três profissionais, ex-proprietários de empresas contábeis, para verificar se as questões estavam inteligíveis.

No que tange à abordagem do problema, a pesquisa caracteriza-se como quantitativa. Richardson $(1999$, p. 70) relata que a abordagem quantitativa caracteriza-se pelo emprego da quantificação tanto nas modalidades de coleta de informações, quanto no tratamento delas por meio de técnicas estatísticas utilizadas. Para a análise dos dados, utilizou-se de estatística descritiva, basicamente frequência e média, além de entropia da informação.

A população da pesquisa compreendeu 1.196 empresas contábeis do estado de Santa Catarina, das quais se identificou o endereço eletrônico e se enviou on-line o instrumento de pesquisa. A amostra compreendeu as 122 empresas contábeis que se dispuseram a responder o instrumento de pesquisa encaminhado por e-mail. Foi solicitado ao contador e/ou responsável responder o questionário e a coleta de dados ocorreu nos meses de setembro a dezembro de 2010. O constructo utilizado neste estudo é apresentado no Quadro 3.

Quadro 3: Constructo da pesquisa para a investigação da presença dos mecanismos isomórficos

\begin{tabular}{|c|c|}
\hline Isomorfismo Mimético & \\
\hline Processos alterados & Atitudes e valores organizacionais da gestão \\
\hline $\begin{array}{l}\text { Controle em geral } \\
\text { Código de ética } \\
\text { Melhorias no layout da empresa } \\
\text { Procedimentos de apuração de resultados } \\
\text { Procedimentos de melhoria contínua nos } \\
\text { controles internos } \\
\text { Realização de estudos para redução de } \\
\text { custos } \\
\text { Mudanças nos sistemas de informações }\end{array}$ & $\begin{array}{l}\text { Valoriza a introdução de novas técnicas de controle } \\
\text { estratégico e gerencial; } \\
\text { Tem como estratégia ser pioneira na adoção de } \\
\text { técnicas de controle de gestão; } \\
\text { Considera que o ambiente organizacional deva } \\
\text { sempre refletir as melhores técnicas de controle de } \\
\text { gestão adotadas no mercado; } \\
\text { A não utilização de determinada técnica é fator } \\
\text { importante para o abandono da mesma; } \\
\text { O apoio dos sócios é importante para o processo } \\
\text { de implementação de novas técnicas de controle de } \\
\text { gestão; } \\
\text { A empresa, ao implementar uma nova técnica adota } \\
\text { seu nome consagrado; } \\
\text { A implementação de nova técnica é cuidadosamente } \\
\text { planejada; } \\
\text { A comunicação da adoção da nova técnica é feita por } \\
\text { meio de reuniões formais; } \\
\text { A introdução de nova técnica é comunicada aos seus } \\
\text { clientes; } \\
\text { A empresa acredita que os seus clientes valorizam a } \\
\text { introdução de novas técnicas e controles de gestão. }\end{array}$ \\
\hline
\end{tabular}

104 Ilse Maria Beuren e Lara Fabiana Dallabona - Presença de mecanismos isomórficos ... 


\begin{tabular}{|c|c|}
\hline \multicolumn{2}{|l|}{ Isomorfismo Normativo } \\
\hline $\begin{array}{l}\text { Perfil desejado para contratação de } \\
\text { funcionários }\end{array}$ & $\begin{array}{l}\text { Meios utilizados para que os funcionários } \\
\text { da área contábil obtenham informações } \\
\text { atualizadas }\end{array}$ \\
\hline $\begin{array}{l}\text { Graduação em Ciências Contábeis } \\
\text { Pós-Graduação em Ciências Contábeis } \\
\text { Experiência anterior na função } \\
\text { Ter dinamismo e determinação } \\
\text { Ter liderança e iniciativa } \\
\text { Ter domínio/compreensão em inglês }\end{array}$ & $\begin{array}{l}\text { Congressos, seminários e palestras } \\
\text { Revistas e jornais de negócios } \\
\text { Consultorias } \\
\text { Visitas a outras empresas do mesmo setor } \\
\text { Reuniões em entidades profissionais } \\
\text { Conversas informais com outros colegas de profissão } \\
\text { Leitura de livros e artigos científicos sobre assuntos } \\
\text { da profissão }\end{array}$ \\
\hline \multicolumn{2}{|l|}{ Isomorfismo Coercitivo } \\
\hline $\begin{array}{l}\text { Padrões internos e externos adotados } \\
\text { na empresa }\end{array}$ & Atendimento de exigências internas e externas \\
\hline $\begin{array}{l}\text { Atende obrigações legais, fiscais e } \\
\text { acessórias previstas em leis e normas } \\
\text { fiscais, tributárias e trabalhistas; } \\
\text { Elabora o planejamento tributário para seus } \\
\text { clientes; } \\
\text { Envia informações mensais de natureza } \\
\text { fiscal, trabalhista e contábil de clientes que } \\
\text { não possuem movimentação; } \\
\text { Investe em tecnologia da informação por } \\
\text { imposição de seus clientes; } \\
\text { Investe em tecnologia da informação por } \\
\text { imposição de órgãos reguladores; } \\
\text { Investe em infraestrutura por imposição de } \\
\text { funcionários; } \\
\text { Investe em infraestrutura por imposição de } \\
\text { seus clientes; } \\
\text { Envia guias de contribuição sindical, } \\
\text { confederativa, assistencial e associativa aos } \\
\text { seus clientes. }\end{array}$ & $\begin{array}{l}\text { Clientes } \\
\text { Funcionários } \\
\text { Governo Federal } \\
\text { Governo Estadual } \\
\text { Governo Municipal }\end{array}$ \\
\hline
\end{tabular}

Fonte: Dados da pesquisa.

Observa-se, no Quadro 3, que para cada tipo de isomorfismo foi elaborado um bloco de questões, de modo que fosse possível verificar, dentre os isomorfismos mimético, normativo e coercitivo, o que mais se destaca no contexto das empresas contábeis do estado de Santa Catarina. Para o isomorfismo mimético, foram elaboradas questões envolvendo os processos alterados e as atitudes e os valores organizacionais utilizados na gestão. No isomorfismo normativo, estruturaram-se questões sobre o perfil desejado para a contratação de funcionários e meios utilizados pela empresa para que seus funcionários obtenham informações atualizadas na área contábil. No isomorfismo coercitivo, abordam-se questões sobre os padrões internos e externos executados pela empresa e atendimento de exigências internas e externas.

Para a tabulação e a análise dos dados, foram utilizadas planilhas eletrônicas, listando as respostas, conforme descrição de escala Likert, tabulando a pontuação 5 para "concordo totalmente"; 4, "concordo"; 3, "indiferente"; 2, "discordo"; e 1, "discordo totalmente". Para obter a média de cada mecanismo isomórfico, os seguintes passos foram seguidos:

a) soma das respostas de cada bloco de pesquisa, conforme pontuação máxima para o respectivo bloco. Por exemplo, blocos com 7 questões poderiam ter pontuação máxima de até 35 pontos. Neste caso, uma empresa que respondeu a opção "concordo totalmente" para todas as perguntas com pontuação 5 atingiu 100 pontos;

b) para encontrar o valor de cada bloco de perguntas, separadas conforme o tipo de mecanismo isomórfico (mimético, normativo e coercitivo), foram multiplicados os resultados dos blocos, dividindo-se o valor por 100. Por exemplo, o bloco de perguntas que analisou o isomorfismo mimético para a empresa " $\mathrm{A}$ " obteve no primeiro cálculo 85 pontos para o primeiro bloco e 80 pontos para o 
segundo bloco, respectivamente. Para o cálculo deste mecanismo isomórfico, multiplicou-se 85 por 80 e dividiu-se este resultado por 100, encontrando-se 68 pontos. Por fim, foi calculada a média conforme resultados apresentados por região geográfica analisada.

Em seguida, foi calculada a entropia da informação, com a finalidade de identificar as empresas, por região, com os índices de isomorfismo de maior distanciamento dos índices médios encontrados na pesquisa. Alguns passos foram necessários para se chegar ao cálculo da entropia, conforme proposto por Zeleny (1982).

Sejam $d_{i}=\left(d_{i}^{1}, d_{i}^{2}, \ldots, d_{i}^{m}\right)$ os valores normalizados, em que $d_{i}^{k}=\frac{x_{i}^{k}}{x_{i}^{*}}$ caracteriza o conjunto $D$,
termos do i-ésimo atributo.

Define-se $\mathrm{D}_{\mathrm{i}}=\sum_{\mathrm{i}}^{\mathrm{m}} \mathrm{d}_{\mathrm{k}}^{\mathrm{k}} ; \mathrm{i}=1,2, \ldots, \mathrm{n}$. A medida de entropia do contraste de intensidade para o i-ésimo atributo

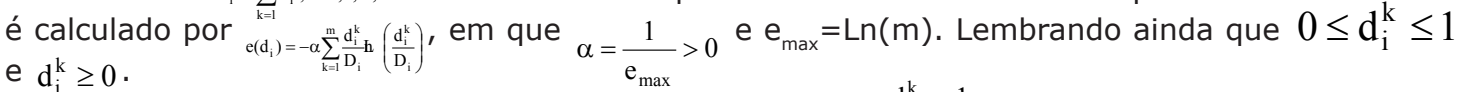

Caso todos os $d_{i}^{k}$ forem iguais para um dado $i$, então $\frac{d_{i}^{k}}{D_{i}}=\frac{1}{n}$ e e $\left(d_{i}\right)$ assume o valor máximo, isto é, $e_{\max }=\operatorname{Ln}(m)$. Ao se fixar $\alpha=\frac{1}{c_{m e n}}$, determina-se $\leq \mathrm{e}\left(\mathrm{d}_{\mathrm{i}}\right) \leq$ para todos os $\mathrm{d}_{\mathrm{i}}{ }^{\prime} \mathrm{s}$. Essa normalização é necessária para efeito comparativo.

A entropia total de $D$ é definida por: $E=\sum_{\mathrm{i}=1}^{\mathrm{n}} \mathrm{e}\left(\mathrm{d}_{\mathrm{i}}\right)$.

Obs. 1: quanto maior for $\mathrm{e}\left(\mathrm{d}_{\mathrm{i}}\right)$, menor é a informação transmitida pelo i-ésimo atributo;

Obs. 2: caso $e\left(d_{i}\right)=e_{\max }=\operatorname{Ln}(m)$, então o i-ésimo atributo não transmite informação e pode ser removida da análise decisória.

Devido ao peso $\tilde{\lambda}_{i}$ ser inversamente relacionado a e $\left(d_{i}\right)$, usa-se $1-e\left(d_{i}\right)$, em vez de $e\left(d_{i}\right)$ e normaliza-se para assegurar que $0 \leq \lambda_{i} \leq 1$ e $\sum_{i=1}^{n} \tilde{\lambda}_{i}=1$.

Assim, a entropia da informação pode ser representada por:

$$
\tilde{\lambda}_{i}=\frac{1}{n-E}\left[1-e\left(d_{i}\right)\right]=\frac{\left[1-e\left(d_{i}\right)\right]}{n-E} .
$$

Destaca-se como principal limitação do estudo a escolha das empresas contábeis de apenas um estado brasileiro, o de Santa Catarina. Em decorrência, os resultados não podem ser generalizados para empresas contábeis de outros Estados brasileiros. Outra limitação diz respeito ao constructo definido para o estudo, uma vez que não se identificou na literatura um conjunto estruturado de aspectos que caracterizam a presença dos mecanismos isomórficos. Da mesma forma, não se identificou um instrumento de pesquisa testado, logo os resultados se restringem às questões formuladas a partir do constructo.

Há de se considerar também como limitação possíveis vieses quanto às respostas obtidas pelos respondentes, considerando possíveis distorções na fidedignidade das respostas. Os questionários favorecem a cobertura de uma área mais ampla, mas a manifestação do respondente pode não corresponder à realidade, é possível que não deseje essa manifestação (SELLTIZ; WRIGHTSMAN; COOK, 1987). Outra limitação se refere à amostra não probabilística, considerando que os resultados se restringem aos membros da população mais acessíveis no momento da pesquisa, por isso os resultados não podem ser considerados para a totalidade das empresas da população.

Destaca-se, ainda, como limitação a utilização de escala do tipo Likert como uma escala intervalar, visto que ela não pretende ser "mais do que uma escala ordinal" (SELLTIZ; WRIGHTMAN; COOK, 1987 , p. 63). Ela proporciona ordenação dos indivíduos por meio de favorabilidade de sua atitude em relação ao objeto de estudo. Assim, pode não ser base para afirmar o quanto determinado indivíduo é mais favorável do que outro, contribuindo assim para eventuais distorções nos resultados, particularmente em relação à utilização de medidas de tendência central, como a média.

\section{DESCRIÇÃO E ANÁLISE DOS DADOS}

Esta seção aborda inicialmente as características dos respondentes da pesquisa, como gênero, faixa etária, função do respondente, parentes na administração. Em seguida, apresenta características das empresas contábeis e a região geográfica a que pertencem. A partir do cálculo de médias das respostas, evidencia a presença dos três tipos de mecanismos isomórficos (mimético, normativo 
e coercitivo), demonstrando quais se destacam em cada região geográfica do estado de Santa Catarina. Por último, apresenta a entropia da informação, ou seja, as regiões em que constam as empresas com os índices de isomorfismo de maior distanciamento dos índices médios encontrados na pesquisa.

\section{Características gerais dos respondentes da pesquisa}

Apresentam-se na Tabela 1 as características dos respondentes. Nesta análise verificam-se gênero, faixa etária e função do respondente; e se há parentes na administração nas respectivas empresas contábeis de Santa Catarina.

Tabela 1: Características dos respondentes

\begin{tabular}{|c|c|c|c|c|c|c|c|}
\hline Itens & Opções & $\begin{array}{l}\text { Respos- } \\
\text { tas }\end{array}$ & $\%$ & Itens & Opções & $\begin{array}{l}\text { Respos- } \\
\text { tas }\end{array}$ & $\%$ \\
\hline Gênero & $\begin{array}{l}\text { Masculino } \\
\text { Feminino }\end{array}$ & $\begin{array}{l}86 \\
36\end{array}$ & $\begin{array}{l}70 \% \\
30 \%\end{array}$ & $\begin{array}{l}\text { Parentes na } \\
\text { administração }\end{array}$ & $\begin{array}{l}\text { Sim } \\
\text { Não }\end{array}$ & $\begin{array}{l}46 \\
76\end{array}$ & $\begin{array}{l}38 \% \\
62 \%\end{array}$ \\
\hline Total & & 122 & $100 \%$ & \multicolumn{2}{|l|}{ Total } & 122 & $100 \%$ \\
\hline $\begin{array}{l}\text { Faixa } \\
\text { etária }\end{array}$ & $\begin{array}{l}\text { Entre } 20 \text { e } 30 \text { anos } \\
\text { Entre } 31 \text { e } 40 \text { anos } \\
\text { Entre } 41 \text { e } 50 \text { anos } \\
\text { Acima de } 50 \text { anos }\end{array}$ & $\begin{array}{l}27 \\
43 \\
32 \\
20\end{array}$ & $\begin{array}{l}22 \% \\
36 \% \\
26 \% \\
16 \%\end{array}$ & $\begin{array}{l}\text { Função do } \\
\text { respondente }\end{array}$ & $\begin{array}{l}\text { Contador (a) } \\
\text { Administrador } \\
\text { (a) } \\
\text { Diretor/gerente } \\
\text { Outras }\end{array}$ & $\begin{array}{l}65 \\
27 \\
18 \\
12\end{array}$ & $\begin{array}{l}53 \% \\
22 \% \\
15 \% \\
10 \%\end{array}$ \\
\hline Total & & 122 & $100 \%$ & Total & & 122 & $100 \%$ \\
\hline
\end{tabular}

Fonte: Dados da pesquisa.

Relacionam-se na Tabela 1 os dados pesquisados dos respondentes. Constatou-se que, dos 122 respondentes, predominou o gênero masculino, com 86 respondentes, sendo que somente 36 são do gênero feminino. Outra constatação é a presença de familiares na administração, verificando-se que 46 respondentes são parentes dos administradores e 76 respondentes não têm vínculo familiar com os administradores.

No que tange à faixa etária, destaca-se que 43 respondentes estão na faixa etária entre $31 \mathrm{e}$ 40 anos, seguido de 32 respondentes com faixa etária entre 41 e 50 anos. Em relação à função, 65 respondentes exercem a função de contador (a) e 27 responderam como função exercida na empresa contábil a de administrador. Os demais 30 respondentes apresentaram como função exercida a de diretor/gerente ou outras.

\section{Características das empresas contábeis pesquisadas e sua região geográfica}

Como características gerais das empresas contábeis foram pesquisadas: a forma de administração da empresa, se é familiar ou de terceiros; se o fundador da empresa permanece na administração ou não; tempo de atividade; número de funcionários; e região geográfica em que a empresa está estabelecida. A Tabela 2 apresenta as características administrativas das empresas contábeis de Santa Catarina pesquisadas. 
Tabela 2: Características administrativas das empresas contábeis pesquisadas

\begin{tabular}{|c|c|c|c|c|c|}
\hline Administração & Total & \% sobre Total & Fundador & Total & $\%$ sobre Total \\
\hline Familiar & 68 & $56 \%$ & $\begin{array}{l}\text { Permanece na } \\
\text { administração }\end{array}$ & 102 & $84 \%$ \\
\hline Terceiros & 54 & $44 \%$ & Não permanece & 20 & $16 \%$ \\
\hline Total & 122 & $100 \%$ & Total & 122 & $100 \%$ \\
\hline
\end{tabular}

Fonte: Dados da pesquisa.

Verifica-se na Tabela 2 que 68 empresas (56\%) da amostra pesquisada são de origem familiar, sendo administradas por membros da família, como pelo pai, filhos, esposo, esposa, irmãos, cunhados, sobrinhos, sogro e/ou sogra. Os demais, 44\%, responderam não ter laços familiares na administração da empresa contábil, considerando, portanto, que sua origem também não se deu por membros de uma mesma família.

Pressupõe-se que empresas familiares atuam em ambientes semelhantes e com desafios similares, o que favorece a característica de isomorfismo, considerando que essas empresas apresentam gestão comum, propriedade única do capital da empresa, sucessão no comando e demais aspectos característicos de empresas familiares (FACCHINI; BEUREN; NASCIMENTO, 2009).

A permanência do fundador da empresa contábil na administração da empresa também foi questionada. Os dados da Tabela 2 mostram que 102 fundadores das empresas contábeis permanecem na administração, e apenas 20 não ocupam mais este cargo de administrador. Na Tabela 3, demonstram-se o tempo de atividade e o número de funcionários das empresas contábeis de Santa Catarina pesquisadas.

Tabela 3: Tempo de atividade e número de funcionários das empresas contábeis pesquisadas

\begin{tabular}{l|l|l|l|l|l}
\hline Tempo atividade & Total & \% sobre Total & No Funcionários & Total & \% sobre Total \\
\hline Até 10 anos & 35 & $29 \%$ & Até 5 & 53 & $43 \%$ \\
De 11 até 20 anos & 54 & $44 \%$ & De 6 até 10 & 37 & $30 \%$ \\
De 21 até 30 anos & 14 & $11 \%$ & De 11 até 15 & 11 & $9 \%$ \\
Acima de 31 anos & 19 & $16 \%$ & Acima de 16 & 21 & $17 \%$ \\
\hline Total & 122 & $100 \%$ & Total & 122 & $\mathbf{1 0 0 \%}$ \\
\hline
\end{tabular}

Fonte: Dados da pesquisa.

Observa-se na Tabela 3 que das 122 empresas contábeis analisadas, 54 estão no intervalo de 11 até 20 anos de atividade, seguido de 35 empresas com tempo de atividade na faixa de até 10 anos, e 19 empresas com mais de 31 anos de atividade. 0 fato de $44 \%$ das empresas pertencentes à amostra apresentarem entre 11 até 20 anos de atividade, sustenta os resultados obtidos sobre os tipos de isomorfismos, considerando que para a respectiva análise se deve atentar ao fato de a empresa contábil ter passado por transformações internas e externas por um determinado período de tempo.

No que tange à quantidade de funcionários que atuam nas empresas contábeis, constata-se que 43\% das empresas possuem até 5 funcionários; 30\% de 5 até 10 funcionários; 9\% de 11 até 15 funcionários; e 17\% acima de 16 funcionários. Esta análise foi realizada, haja vista que questões relacionadas à profissionalização exigida pelas empresas contábeis foram foco para verificar a presença do isomorfismo normativo. Para análise da distribuição geográfica das empresas contábeis participantes deste estudo, elaborou-se a Tabela 4. 
Tabela 4: Região geográfica das empresas contábeis pesquisadas

\begin{tabular}{l|l|l|l|l}
\hline \multirow{2}{*}{ Região Geográfica } & \multicolumn{2}{|l|}{ População } & \multicolumn{2}{l}{ Amostra } \\
\cline { 2 - 5 } & $\begin{array}{l}\text { N Empresas } \\
\text { Contábeis }\end{array}$ & $\begin{array}{l}\text { \% de Empresas } \\
\text { Contábeis }\end{array}$ & $\begin{array}{l}\text { No Empresas } \\
\text { Contábeis }\end{array}$ & $\begin{array}{l}\text { \% de Empresas } \\
\text { Contábeis }\end{array}$ \\
\hline Grande Florianópolis & 257 & $22 \%$ & 26 & $21 \%$ \\
Norte Catarinense & 165 & $14 \%$ & 12 & $10 \%$ \\
Oeste Catarinense & 219 & $19 \%$ & 20 & $16 \%$ \\
Sul Catarinense & 88 & $8 \%$ & 5 & $4 \%$ \\
Serra Catarinense & 76 & $6 \%$ & 2 & $2 \%$ \\
Vale do Itajaí & 361 & $31 \%$ & 57 & $47 \%$ \\
\hline Total & 1.166 & $100 \%$ & 122 & $\mathbf{1 0 0 \%}$ \\
\hline
\end{tabular}

Fonte: Dados da pesquisa.

Nota-se na Tabela 4, sobre a distribuição geográfica das empresas contábeis pesquisadas, que a região do Vale do Itajaí foi a que apresentou maior percentual de participação, com $47 \%$. As empresas contábeis que participaram deste estudo que se encontram no Vale do Itajaí estão localizadas nas cidades de Blumenau, Indaial, Timbó, Brusque e Gaspar. Com 21\% está a região da Grande Florianópolis, destacando-se as cidades de São José e Florianópolis. A região Oeste Catarinense ficou em terceiro lugar, com $16 \%$ de participação; seguido da região Norte Catarinense, com 10\%; e as regiões Sul e Serra Catarinense, com 4\% e 2\% de participação, respectivamente. A identificação da distribuição geográfica das empresas respondentes da pesquisa permite apresentar o mecanismo isomórfico (mimético, normativo e coercitivo) que se destaca em cada região catarinense.

\section{Presença de isomorfismo nas empresas contábeis pesquisadas por região geográfica}

Esta seção evidencia as médias dos três tipos de mecanismos isomórficos (mimético, normativo e coercitivo) presentes nas empresas contábeis de Santa Catarina que compõem a amostra da pesquisa. Apresentam-se, portanto, as médias calculadas para cada mecanismo isomórfico, demonstrando a predominância de isomorfismo por região geográfica.

A Figura 1 apresenta a média dos isomorfismos nas empresas contábeis pertencentes à região da Grande Florianópolis, com destaque para os itens que foram analisados conforme o constructo da pesquisa do Quadro 3.

Figura 1: Média dos três tipos de mecanismos isomórficos presentes nas empresas contábeis pertencentes à região da Grande Florianópolis

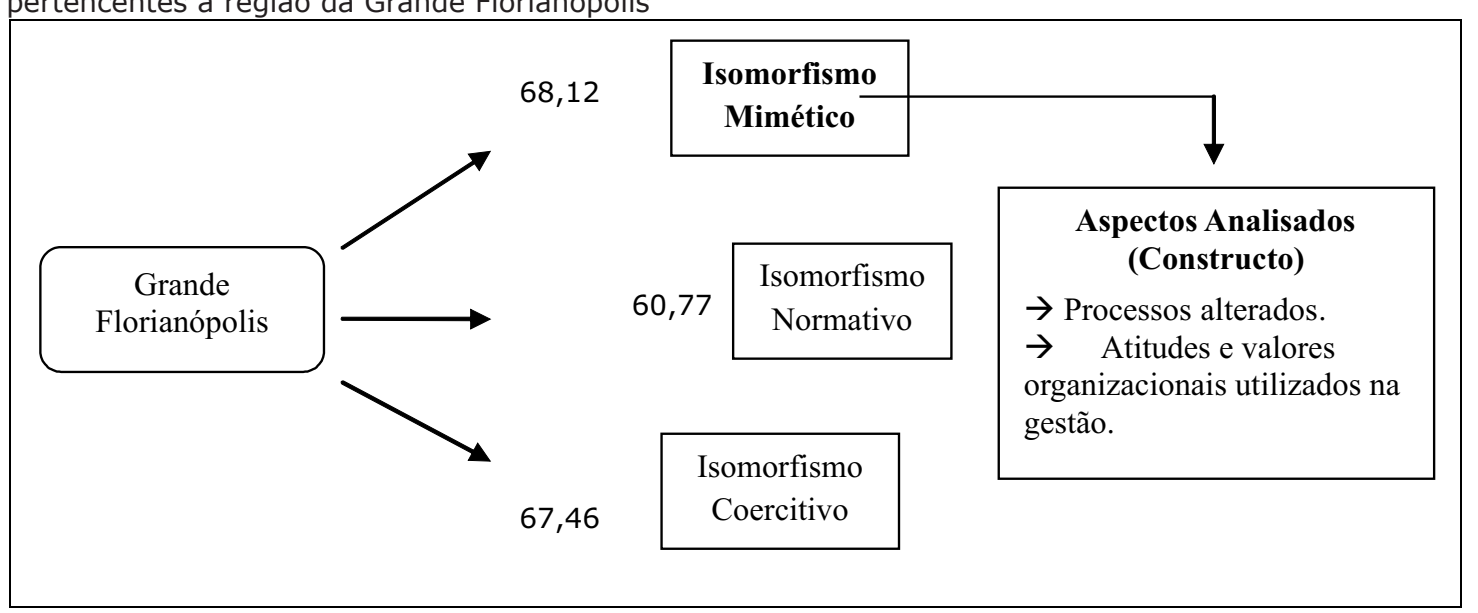

Fonte: Dados da pesquisa. 
Observa-se na Figura 1 que o isomorfismo predominante na região da Grande Florianópolis foi o isomorfismo mimético, apresentando maior média dentre os isomorfismos analisados $(68,12)$. 0 isomorfismo mimético é muitas vezes influenciado por questões de incerteza, no qual as organizações, se deparando com concorrentes que obtiveram sucesso na implantação de determinadas técnicas organizacionais, tenderão a copiar os respectivos modelos e/ou técnicas organizacionais para obter sucesso similar (DIMAGGIO; POWELL, 1991).

Os resultados ora apresentados nas Figuras 1 e 2 são condizentes com a pesquisa de Oyadomari et al. (2008), que demonstraram ser o isomorfismo mimético o mais relevante na implantação e na adoção de práticas e instrumentos gerenciais. Isso pode estar diretamente relacionado às questões de incertezas, utilizando-se de outras organizações bem-sucedidas como espelho, para tornaremse bem-sucedidas. As regiões Oeste Catarinense e Serra Catarinense também apresentaram predominância do isomorfismo mimético, conforme se demonstra na Figura 2.

Figura 2: Média dos três tipos de mecanismos isomórficos presentes nas empresas contábeis pertencentes às regiões Oeste Catarinense e Serra Catarinense

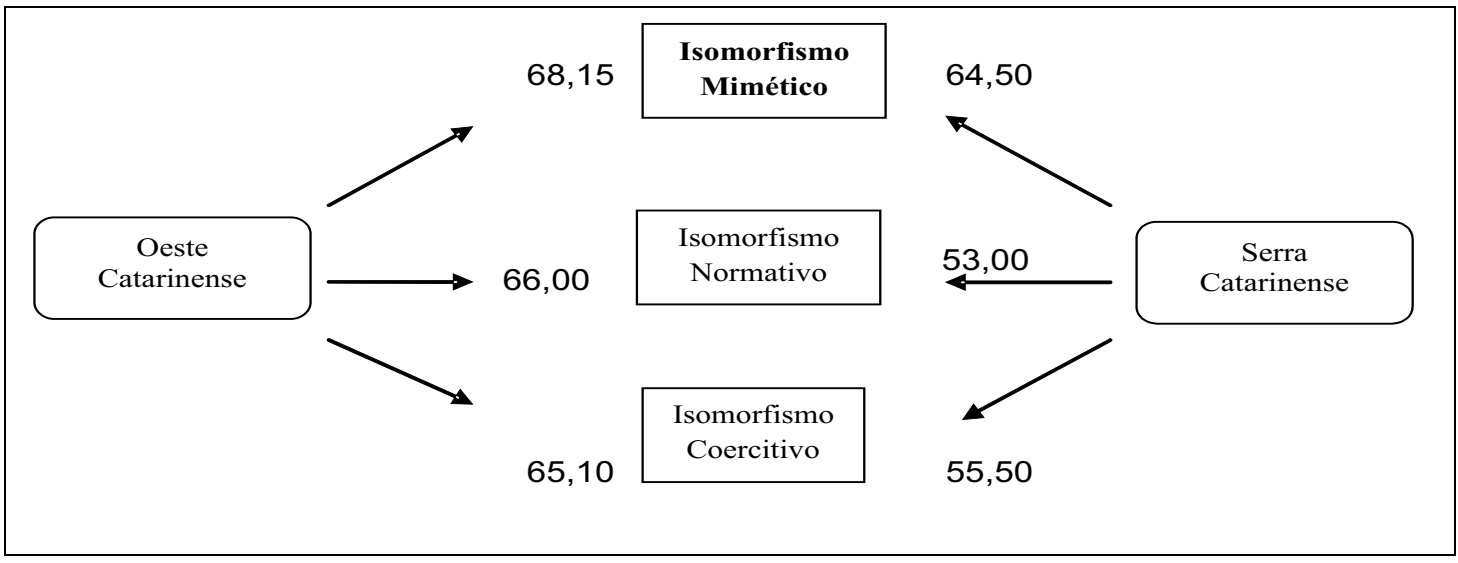

Fonte: Dados da pesquisa.

Dentre as questões analisadas para o isomorfismo mimético que se destacaram têm-se: controle geral da empresa, aspectos éticos, melhorias no layout da empresa, procedimentos de apuração de resultados e melhoria contínua nos controles internos. Comparando estes resultados com o relato de Sacomano Neto, Truzzi e Kirschbaum (2010), destaca-se que quanto mais dependente uma organização for de outra, sob vários aspectos, como, por exemplo, aspectos culturais, sociais etc., maior será sua similaridade com as organizações a sua volta, tanto em termos de estrutura, ambiente e/ou similaridade comportamental.

Na Figura 3 apresenta-se o isomorfismo predominante da região Norte Catarinense, com destaque aos principais aspectos analisados quanto ao mecanismo isomórfico em destaque. 
Figura 3: Média dos três tipos de mecanismos isomórficos presentes nas empresas contábeis pertencentes à região Norte Catarinense

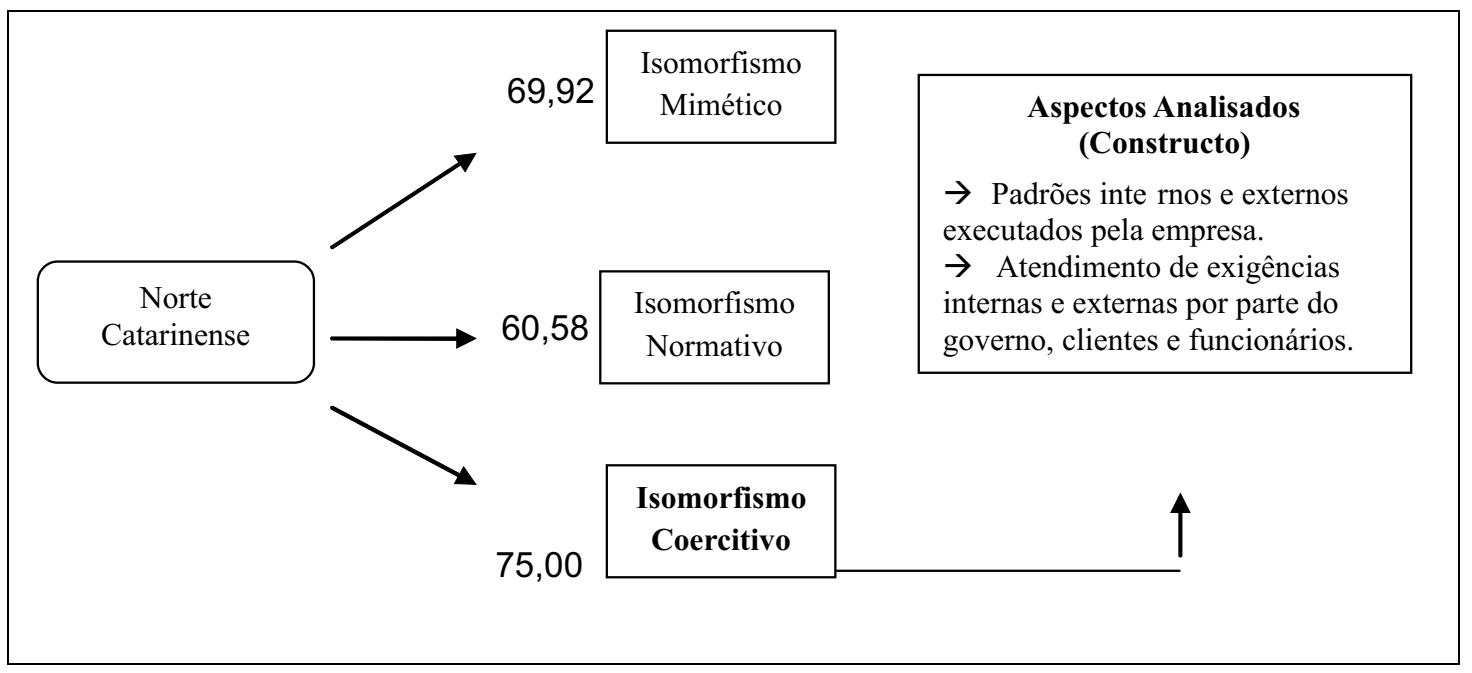

Fonte: Dados da pesquisa.

Verifica-se, na Figura 3, que na região Norte Catarinense, diferente da região da Grande Florianópolis, os dados se inverteram e o isomorfismo predominante passou a ser o coercitivo. Conforme Dimaggio e Powell (1983), este tipo de isomorfismo é resultante de influências políticas e do problema da legitimação como resultado de pressões formais e informais, exercidas por outras organizações e pela sociedade na qual as empresas atuam.

Neste caso, a forte influência dos órgãos governamentais sobre as empresas prestadoras de serviços contábeis pode ser considerada uma fonte indutora deste tipo de mecanismo isomórfico, uma vez que as imposições legais devem ser seguidas corretamente pelas empresas contábeis para que não venham a incorrer em prejuízos futuros.

Rosseto (2003), analisando como o isomorfismo institucional influenciou a formulação estratégica de três empresas do ramo da construção civil, verificando as adaptações estratégicas em ambientes com fortes turbulências e influências governamentais, concluiu que os isomorfismos com maior influência foram: o mimético, o coercitivo e, por fim, o isomorfismo normativo, assim como os dados apresentados neste estudo. Outras duas regiões que apresentaram predominância do isomorfismo coercitivo foram as regiões Sul Catarinense e Vale do Itajaí, apresentando uma média de 73,60 e 73,35 respectivamente.

Figura 4: Média dos três tipos de mecanismos isomórficos presentes nas empresas contábeis pertencentes às regiões Sul Catarinense e Vale do Itajaí

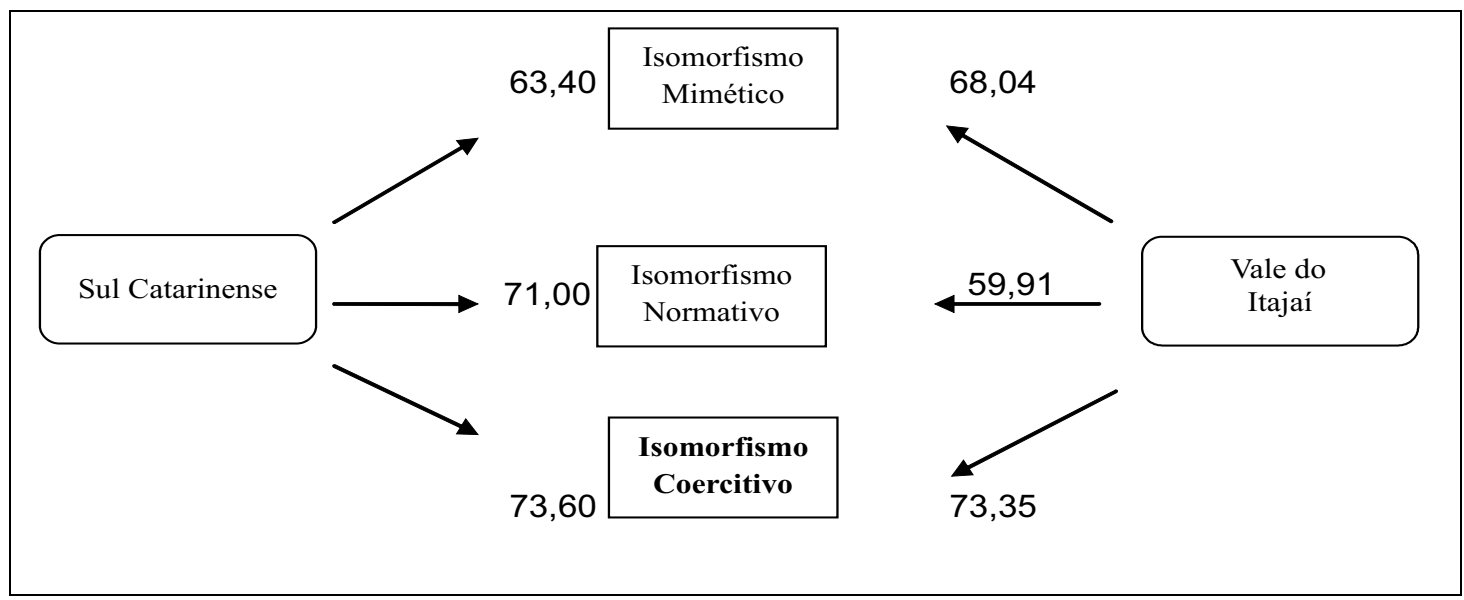

Fonte: Dados da pesquisa. 
Observa-se na Figura 4 que a segunda maior média entre os mecanismos isomórficos analisados está o isomorfismo normativo para a região Sul Catarinense $(71,00)$. Dos dados analisados quanto ao isomorfismo normativo, estão questões relacionadas ao perfil desejado para contratação de funcionários e meios utilizados pela empresa para que seus funcionários obtenham informações atualizadas na área contábil, conforme pode ser observado no constructo do estudo.

No contexto do isomorfismo normativo, "as organizações mudam para atender padrões de profissionalismo, para adotar técnicas que são consideradas pela comunidade profissional como atualizadas e eficazes" (DAFT, 1999, p. 348). É por meio de congressos, seminários, acesso a leituras em revistas, livros e jornais, visitas formais a outras empresas, conversas informais com colegas de trabalho, que o profissional adquire conhecimentos específicos de sua área, aumentando a predominância desse tipo de isomorfismo.

\section{Entropia da informação dos três tipos de mecanismos isomórficos presentes nas empresas contábeis de Santa Catarina}

Após demonstrar as médias dos três tipos de mecanismos isomórficos (mimético, normativo e coercitivo) por região, para enriquecer a análise, foi verificado por meio da entropia da informação qual tipo de isomorfismo apresentou maior variação em relação à média, entre os escritórios de cada região, conforme se apresenta na Tabela 5.

Tabela 5: Entropia da informação dos três tipos de mecanismos isomórficos presentes nas empresas contábeis de Santa Catarina

\begin{tabular}{|c|c|c|c|c|c|c|c|c|c|}
\hline Região & $\begin{array}{l}\text { Entropia } \\
\text { e( }\left(d_{i}\right)\end{array}$ & $\begin{array}{c}\text { Mimético } \\
\text { Peso da } \\
\text { Questão } \\
\tilde{\mathrm{I}}_{i}\end{array}$ & Média & $\begin{array}{c}\text { Entropia } \\
\text { e( }\left(d_{i}\right)\end{array}$ & $\begin{array}{c}\text { Vormativo } \\
\text { Peso da } \\
\text { Questão } \\
\tilde{\mathrm{I}}_{i}\end{array}$ & Média & $\begin{array}{c}\text { Entropia } \\
e\left(d_{i}\right)\end{array}$ & $\begin{array}{c}\text { oersitivo } \\
\text { Peso da } \\
\text { Questão } \\
\tilde{\mathrm{I}}_{i}\end{array}$ & Média \\
\hline Norte & 0,9890 & 0,5494 & 69,92 & 0,9949 & 0,2553 & 60,58 & 0,9961 & 0,1953 & 75,00 \\
\hline Sul & 0,9966 & 0,1037 & 63,40 & 0,9954 & 0,1379 & 71,00 & 0,9749 & 0,7585 & 73,60 \\
\hline Serra & 0,9579 & 0,5186 & 64,50 & 0,9742 & 0,3185 & 53,00 & 0,9868 & 0,1629 & 55,50 \\
\hline Oeste & 0,9903 & 0,3257 & 68,15 & 0,9943 & 0,1924 & 66,00 & 0,9857 & 0,4818 & 65,10 \\
\hline $\begin{array}{l}\text { Grande } \\
\text { Florianó- } \\
\text { polis }\end{array}$ & 0,9950 & 0,2265 & 68,12 & 0,9916 & 0,3854 & 60,77 & 0,9915 & 0,3880 & 67,46 \\
\hline $\begin{array}{l}\text { Vale } \\
\text { Itajaí }\end{array}$ & 0,9949 & 0,2895 & 68,04 & 0,9952 & 0,2688 & 59,91 & 0,9922 & 0,4417 & 73,35 \\
\hline
\end{tabular}

Nota-se na Tabela 5, em relação à região Norte Catarinense, que o maior $\mathrm{e}\left(\mathrm{d}_{\mathrm{i}}\right)=0,9961$ refere-se ao isomorfismo coercitivo, ou seja, essa questão apresenta a menor informação transmitida. Segundo Zeleny (1982), quanto maior for o e $\left(\mathrm{d}_{\mathrm{i}}\right)$, menor é a informação transmitida. Nesse caso, menor é a variação em relação à média $(75,00)$, ou seja, pouquíssimas empresas obtiveram resultados muito diferentes da pontuação média encontrada na pesquisa.

Analisando o peso $\left(\tilde{I}_{i}\right)$ de cada questão, calculado em relação aos três tipos de mecanismos isomórficos, observa-se na região Norte que o maior peso $\left(I_{i}=0,5494\right)$ foi do isomorfismo mimético, o que demonstra que um número maior de empresas obteve índices que se distanciam da média encontrada. 
A região da Serra Catarinense é a que apresenta os menores e $\left(d_{i}\right)(0,9579 ; 0,9742 ; 0,9868)$ dentre todas as regiões. Dessa maneira, infere-se que esta é a região que possui o maior número de empresas com índices que se distanciam da média encontrada para cada tipo de mecanismo isomórfico.

A região com os maiores e $\left(d_{i}\right)(0,9949 ; 0,9952 ; 0,9822)$ foi a do Vale do Itajaí. Portanto é a região com o menor número de empresas que se distanciam da média encontrada para cada tipo de isomorfismo. De forma geral, todas as regiões apresentaram e $\left(d_{i}\right)$ próximos a 1 , ou seja, ocorreu pouco distanciamento dos índices de isomorfismo em relação às médias.

\section{CONCLUSÕES}

O estudo objetivou verificar a presença dos três tipos de mecanismos isomórficos (mimético, coercitivo e normativo) da Nova Sociologia Institucional (New Institutional Sociology - NIS) em empresas contábeis. Pesquisa descritiva, com abordagem quantitativa, foi realizada por meio de um levantamento em uma amostra por acessibilidade de 122 empresas contábeis, compreendendo as que responderam o instrumento de pesquisa encaminhado por e-mail ao contador e/ou responsável. Para análise dos dados, utilizou-se da estatística descritiva e entropia da informação.

Os resultados mostraram que, dos respondentes da pesquisa, $70 \%$ são do gênero masculino e $30 \%$ feminino. Este aspecto chamou atenção, uma vez que nos cursos de graduação em Ciências Contábeis já está prevalecendo o gênero feminino entre os alunos. Grande parte $(36 \%)$ dos respondentes está na faixa etária entre 31 e 40 anos, portanto são jovens empreendedores, considerando que 102 das empresas pesquisadas contam com o fundador em sua administração. As principais funções dos respondentes apontadas na pesquisa são de contador(a), administrador(a) e diretor/gerente.

Contatou-se que $56 \%$ das empresas contábeis são de origem familiar e atuam entre 11 e 20 anos no mercado. Em relação à quantidade de funcionários, $43 \%$ das empresas contábeis contam com até cinco funcionários, seguido de $30 \%$ das empresas com 6 até 10 funcionários. Estes aspectos tendem a favorecer a presença de fatores miméticos entre estas empresas. Quanto à região geográfica das empresas contábeis pesquisadas, a que apresentou maior percentual participativo foi a região do Vale do Itajaí, com 47\%. Esses percentuais são proporcionalmente condizentes com a população total da pesquisa que é de 1.166 escritórios contábeis, dos quais, a grande maioria localiza-se no Vale do Itajaí e na Grande Florianópolis.

Analisando-se sob o enfoque de diferentes categorias a presença dos três tipos de mecanismos isomórficos nas empresas contábeis, constatou-se que na região da Grande Florianópolis, Oeste Catarinense e Serra Catarinense prevaleceu o isomorfismo mimético. Destaca-se que nestas regiões estão localizadas as empresas contábeis que atuam há mais tempo no mercado e com maior número de funcionários, o que sugere que são mais consolidadas e que servem de exemplo às outras. Já nas regiões Norte Catarinense, Sul Catarinense e Vale do Itajaí, prevaleceu o isomorfismo coercitivo. Nessas regiões, os escritórios possuem menor tempo de atuação no mercado, portanto, ainda buscam sua legitimidade, sofrem mais com pressões externas e não possuem referências para seguirem.

Conclui-se, portanto, que nas análises vislumbradas no estudo, o isomorfismo mimético e o isomorfismo coercitivo se fazem presentes nas atividades operacionais das empresas contábeis de Santa Catarina, com maior intensidade para o isomorfismo coercitivo. Outro aspecto que chamou atenção decorre do fato de não se ter constatado em nenhum momento das análises, um percentual maior para o isomorfismo normativo.

Uma possível explicação para a predominância do isomorfismo coercitivo nas categorias analisadas está na forte relação das empresas prestadoras de serviços contábeis com órgãos governamentais, como governo federal, estadual e municipal, haja vista a dependência dos respectivos órgãos reguladores. Outra explicação decorre da pressão exercida por organizações externas para que as respectivas empresas contábeis adotem procedimentos semelhantes entre si, conforme citado por Draft (1999).

Os resultados demonstraram também, por meio da entropia, que a maioria das empresas contábeis possui índices de isomorfismo muito próximos dos índices médios encontrados no estudo, 
comprovando assim a veracidade dos dados. A região da Serra Catarinense foi a que apresentou o maior número de empresas com índices que se distanciam do índice médio encontrado para cada tipo de isomorfismo; e a região do Vale do Itajaí é a com o menor número de empresas que se distancia do índice médio. De forma geral, todas as regiões apresentaram e $\left(\mathrm{d}_{\mathrm{i}}\right)$ próximos a 1 , ou seja, ocorreu pouco distanciamento dos índices de isomorfismo em relação às médias encontradas.

A relevância dos achados da pesquisa está no padrão seguido pelas empresas contábeis para a realização de suas atividades. Depreende-se dos resultados da pesquisa que empresas prestadoras de serviços contábeis, tanto de cunho familiar quanto de terceiros, espelham-se em empresas concorrentes para legitimarem suas atividades, tornando-se similares, revelado pela presença do isomorfismo mimético. Também se utilizam de regras, normas, leis e regulamentos para desenvolverem suas atividades, o que justifica a influência dos órgãos reguladores da profissão contábil, evidenciado pela forte presença do isomorfismo coercitivo.

Diante dos resultados apresentados e das limitações do estudo, recomenda-se para investigações futuras a reaplicação da pesquisa em outros estados brasileiros, a fim de comparar os resultados encontrados. Outra recomendação decorrente do fato de se utilizar um instrumento de pesquisa desenvolvido especificamente para este estudo, que ele seja aprimorado por meio da aplicação em outras empresas brasileiras, sem ter como foco empresas contábeis, para verificar a presença dos mecanismos isomórficos nestas empresas.

\section{REFERÊNCIAS}

AMARAL FILHO, R. G.; MACHADO-DA-SILVA, C. L. Estratégia e teoria institucional: uma proposta discursiva de integração. In: EnANPAD, 30., 2006, Salvador. Anais... Rio de Janeiro: ANPAD, 2006. CD-ROM.

BARLEY, S. R.; TOLBERT, P. S. Institutionalization and structuration: studying the links between action and institution. Organization Studies, v. 18, n. 1, p. 93-117, 1997.

CARSTEN, D. D. S.; MACHADO-DA-SILVA, C. L. Estratégia e estrutura de relacionamentos na rede de empresas Alpha. In: EnANPAD, 30., 2006, Salvador. Anais... Rio de Janeiro: ANPAD, 2006. CD-ROM.

CORAIOLA, D. M.; MACHADO-DA-SILVA, C. Discurso organizacional e isomorfismo institucional: as mudanças gráficas em jornais brasileiros. Revista Eletrônica de Ciência Administrativa, v. 7, n. 2, p. $1-13$, nov./2008.

DAFT, R. L. Teoria e projeto das organizações. 6. ed. Rio de Janeiro: LTC, 1999.

DIMAGGIO, P. J.; POWELL, W. W. The Iron cage revisited: institutional isomorphism and collective rationality in organizational fields. American Sociological Review, v. 48, n. 2, p. 147-169, Apr. 1983.

FREITAS, C. A. S. Aprendizagem, isomorfismo e institucionalização: o caso da atividade de auditoria operacional no Tribunal de Contas da União. 2005. Dissertação (Mestrado em Administração) - Programa de Pós-Graduação em Administração da Universidade de Brasília, Brasília, 2005.

FREZATTI, F.; AGUIAR, A. B.; REZENDE, A. J. Respostas estratégicas às pressões institucionais e sucesso no atingir metas no orçamento: um estudo em uma empresa multinacional. Revista Organizações \& Sociedade, v. 14, n.43, p. 141-158, out./dez. 2007.

FACHINI, G. J.; BEUREN, I. M.; NASCIMENTO, S. Evidências de isomorfismo nas funções da controladoria das empresas familiares têxteis de Santa Catarina. In: CONGRESSO BRASILEIRO DE CUSTOS, 16., 2009, Fortaleza. Anais... São Leopoldo: ABC, 2009. CD-ROM.

GUERREIRO, R. A. Abordagem institucional na contabilidade gerencial. Revista Contabilidade \& Finanças, São Paulo, n. 40, p. 3-6, jan./abr. 2006.

GUERREIRO, R.; PEREIRA, C. A.; FREZATTI, F. Aplicação do modelo de Burns e Scapens para avaliação do processo de institucionalização da contabilidade gerencial. Revista Organizações \& Sociedade, v. 15, n. 44, jan./mar. 2008.

GIMENEZ, F. A. P; HAYASHI JÚNIOR, P.; GRAVE, P. S. Isomorfismo mimético em estratégia: uma ferramenta para investigação. Revista de Administração Mackenzie, São Paulo, v. 8, n. 4, p. 35-59, 2007. 
GIL, A. C. Como elaborar projetos de pesquisa. São Paulo: Atlas, 1999.

GUERREIRO, R.; PEREIRA, C. A.; LOPES, A. B. Uma contribuição ao entendimento da estabilidade e da mudança da contabilidade gerencial sob a ótica da teoria institucional. In: EnANPAD, 18., 2004, Curitiba. Anais... Rio de Janeiro: ANPAD, 2004. CD-ROM.

IUDÍCIBUS, S. Teoria da contabilidade. 7 ed. São Paulo, Atlas: 2004.

MACHADO-DA-SILVA, C. L.; FONSECA, V. S. Homogeneização e diversidade organizacional: uma visão integrativa. In: EnANPAD, 23., 1993, Salvador. Anais... Rio de Janeiro: ANPAD, 1993.

MACHADO-DA-SILVA, C. L.; FONSECA, V. S.; CRUBELLATE, J. M. Estrutura, agência e interpretação: elementos para uma abordagem recursiva do processo de institucionalização. RAC. Revista de Administração Contemporânea, v. 9, 1. ed. Especial, p. 9-39, 2005.

MACHADO-DA-SILVA, C. L.; COSER, C. Rede de relaçőes interorganizacionais no campo organizacional de Videira-SC. RAC. Revista de Administração Contemporânea, v. 10, n. 4, p. 09-45, out./dez. 2006.

MARTINS, G. A.; THEÓPHILO, C. R. Metodologia da investigação científica para ciências sociais aplicadas. São Paulo: Atlas, 2007.

MARTINS, G. A. Manual para elaboração de monografias e dissertações. 3. ed. São Paulo: Atlas. 2002.

MORAES JUNIOR, V. F.; ARAÚJO, A. O. Características do controle interno nas empresas de serviços contábeis. In: CONGRESSO USP DE CONTROLADORIA E CONTABILIDADE, 6., 2006, São Paulo. Anais... São Paulo: FEA/USP, 2006. CD-ROM.

MÜLLER, E. T. C.; BEUREN, I. M. Evidências de institucionalização da controladoria em empresas familiares brasileiras. In: CONGRESSO ANPCONT, 2., 2008, Salvador. Anais... São Paulo: ANPCONT, 2008. CD-ROM.

OYADOMARI, J.C.T.; MENDONÇA NETO, O.R.; CARDOSO, R.L.; JUNQUEIRA, E. A Institucionalização da VBM - Value Based Management como prática de contabilidade gerencial: uma análise à luz da NIS - New Institutional Sociology. In: CONGRESSO USP DE CONTROLADORIA E CONTABILIDADE, 7., 2007, São Paulo. Anais... São Paulo: FEA/USP, 2007. CD-ROM.

OYADOMARI, J.C.T.; CARDOSO, R.L.; MENDONÇA NETO, O.R.; LIMA, M. P. Fatores que influenciam a adoção de artefatos de controle gerencial nas empresas brasileiras. Um estudo exploratório sob a ótica da teoria neo-institucional. In: CONGRESSO USP DE CONTROLADORIA E CONTABILIDADE, 8., 2008, São Paulo. Anais... São Paulo: FEA/USP, 2008. CD-ROM.

PASSALONGO, C.; ICHIKAWA, E. Y.; REIS, L. G. Contribuições da teoria institucional para os estudos organizacionais: o caso da Universidade Estadual de Londrina. Revista de Negócios, Blumenau, v. 9, n. 1, p. 19-26, jan./mar. 2004.

RICHARDSON, R. J. Pesquisa social: métodos e técnicas. 3. ed. São Paulo: Atlas, 1999.

REZENDE, A. J.; GUERREIRO, R. Uma análise do isomorfismo reverso das práticas contábeis de correção monetária. In: CONGRESSO ANPCONT, 4., 2010, Natal. Anais... São Paulo: ANPCONT, 2010. CD-ROM.

RIBEIRO, J. A.; SCAPENS, R. W. Institutional theories in management accounting change contributions, issues and paths for development. Qualitative Research in Accounting \& Management, v. 3, n. 2, p. $94-111,2006$.

ROSSONI, L.; MACHADO-DA-SILVA, C. Institucionalismo Organizacional e Práticas de Governança Corporativa. RAC. Revista de Administração Contemporânea, Edição Especial, art. 7, p. 173-198, 2010.

ROSSETTO, C. R. Formulação estratégica organizacional na ótica do isomorfismo: um estudo multicaso de empresas familiares. In: ENCONTRO DE ESTUDOS SOBRE EMPREENDEDORISMO E GESTÃO DE PEQUENAS EMPRESAS. 3., 2003, Brasília. Anais... Brasília: UEM/UEL/UnB, 2003. CD-ROM.

ROSSETTO, C. R.; ROSSETTO, A. M. Teoria institucional e dependência de recursos na adaptação organizacional: uma visão complementar. RAE-eletrônica, v. 4, n. 1, Art. 7, jan./jul. 2005.

SACOMANO NETO, M.; TRUZZI, O. M. S.; KIRSCHBAUM, C. Isomorfismo institucional e capacidade de controle: um estudo em uma planta modular da indústria automobilística. In: EnANPAD, 34., 2010, Rio de Janeiro. Anais... Rio de Janeiro: ANPAD, 2010. CD-ROM. 
SELLTIZ, C.; WRIGHTSMAN, L.S.; COOK, S.W. Métodos de pesquisa nas relações sociais. 2. ed. São Paulo, EPU, 1987.

TOLBERT, P. S.; ZUCHER, L. G. A institucionalização da teoria institucional. In: CALDAS, M.; FACHIN, R.; FISCHER, T. (Orgs.). Handbook de Estudos Organizacionais: modelos de análise e novas questões em estudos organizacionais. São Paulo: Atlas, 1999.

ZELENY, M. Multiple criteria decision making. New York: McGraw-Hill, 1982. 